\title{
47. ACOUSTIC PROPERTIES OF TUFFACEOUS AND CALCAREOUS SEDIMENTS, DEEP SEA DRILLING PROJECT LEG 60 ${ }^{1}$
}

\author{
R. L. Carlson, Department of Geophysics and Geodynamics Research Program, \\ Texas A\&M University, College Station, Texas
}

\section{INTRODUCTION}

Laboratory measurements of physical properties are important because the results may be applied to the interpretation of seismic and other types of geophysical data, and because they can be used to estimate the in situ physical properties of different lithologies present beneath the sea floor. In this chapter, wet-bulk densities and compressional-wave velocities, measured at elevated confining pressures, are reported for a suite of seven sediment samples recovered on DSDP Leg 60 . Of the seven samples studied, two are mudstones, two are vitric tuffs, and three are chalks. All but one of the samples are from Hole 459B, near the eastern limit of the Mariana fore-arc region. In five cases, velocities were measured parallel and perpendicular to bedding to test for velocity anisotropy.

\section{METHODS}

Samples in the form of "mini-cores," $2.54 \mathrm{~cm}$ in diameter, were sent to the shore laboratory in a partially water-saturated condition. Since the extent of water saturation is known to have a significant effect on compressional-wave velocities in rocks (e.g., Wyllie et al., 1958; Nur and Simmons, 1969; Christensen, 1970), the samples were brought to full saturation by soaking in fresh water for approximately 20 days. Some samples were re-cut to a diameter of $2.00 \mathrm{~cm}$, and the ends of the cores were subsequently trimmed and lapped smooth to form right circular cylinders 2 to $3 \mathrm{~cm}$ long.

The wet-bulk density values reported in Table 1 were measured using a Jolly balance. Sample densities were independently estimated from the weights and computed volumes of the cylindrical cores, and in most cases the densities determined by these two methods agree to within $\pm 0.02 \mathrm{~g} / \mathrm{cm}^{3}$. The Jolly balance values are taken to be more reliable owing to the presence of chips and other irregularities in the cylinders. These densities compare favorably with shipboard measurements made on samples from adjacent portions of the drill core.

Prior to the pressure runs, the cylinders were wrapped in a single layer of 100-mesh screen and jacketed with copper foil to prevent the pressure medium from entering the rock. The screen provides voids into which pore water can escape from the sample at elevated confining pressures. Consequently, pore pressures are maintained at levels substantially lower than the pressure of the confining medium. Compressional-wave velocities were measured using $1-\mathrm{MHz}$ leadzirconate-titanate (PZT-5) transducers, by the pulse-transmission method (Birch, 1960) at confining pressures to $0.6 \mathrm{kbar}$.

Depth of recovery, wet-bulk densities, velocities, and brief lithologic descriptions are presented in Table 1.

\section{DISCUSSION}

Velocity-density relations for the Leg 60 sediments are illustrated in Figure 1. Included for comparison are

\footnotetext{
${ }^{1}$ Initial Reports of the Deep Sea Drilling Project, Volume 60.
}

data for a variety of previously studied samples recovered by the Deep Sea Drilling Project: basalts (Christensen and Salisbury, 1972, 1973; Christensen, 1973a, b; Christensen, Fountain, et al., 1974; Christensen, Salisbury, et al., 1974; Carlson and Christensen, 1977a), deep-sea carbonates (Christensen et al., 1973; Christensen, Fountain, et al., 1974; Christensen, Salisbury, et al., 1974; Carlson and Christensen 1977b; Carlson and Christensen, 1979), and vitric tuffs from the Philippine Sea (Carlson et al., in press). Lines connect data points for separate samples in which velocities have been measured parallel and perpendicular to bedding. In the carbonates, higher velocities are observed for propagation in the bedding plane in all cases (Carlson and Christensen, 1979), whereas in the vitric tuffs from DSDP Leg 59 apparent variations in velocity with direction of propagation result largely from differences in sample density (Carlson et al., in press).

The mudstone samples are interesting in that their velocities and densities fall within the range of data for vitric tuffs. The massive mudstone is isotropic, whereas the laminated mudstone shows a significant degree of velocity anisotropy. This anisotropy does not result from the alignment of pore spaces in the bedding or lamination planes, as evidenced by the fact that the difference between the horizontal and vertical velocities does not decrease with increasing confining pressure (see Table 1).

Data from the two tuff samples conveniently fall within a range for similar tuffs from Leg 59 . Velocities were measured parallel and perpendicular to bedding in only one of these samples, which is anisotropic, in marked contrast to the other vitric tuff samples. The difference may lie in the fact that the tuffs from Leg 59 are massive and coarse-grained, whereas the anisotropic tuff recovered on Leg 60 has a fine-grained sandy-tosilty character with well-developed bedding.

The properties of the carbonate samples correlate well with data from previous studies.

\section{ACKNOWLEDGMENTS}

1 am particularly indebted to Dr. N. I. Christensen for the use of his high-pressure laboratory. J. Schultz maintained the high-pressure system, and assisted in developing improved techniques for making velocity measurements in sediments. This research was supported by NSF Grant OCN-7817919.

\section{REFERENCES}

Birch, F., 1960. The velocity of compressional waves in rocks to 10 kilobars, 1. J. Geophys. Res., 65:1083-1102. 
Table 1. Summary of acoustic properties, Leg 60.

\begin{tabular}{|c|c|c|c|c|c|c|c|c|c|c|}
\hline \multirow{2}{*}{$\begin{array}{l}\text { Sample } \\
\text { (interval in } \mathrm{cm} \text { ) }\end{array}$} & \multirow{2}{*}{$\begin{array}{l}\text { Depth } \\
\text { (m) }\end{array}$} & \multirow{2}{*}{$\begin{array}{l}\text { Density } \\
\left(\mathrm{g} / \mathrm{cm}^{3}\right)\end{array}$} & \multirow{2}{*}{$\begin{array}{l}\text { Propagation } \\
\text { Direction }^{\mathrm{a}}\end{array}$} & \multicolumn{6}{|c|}{$\begin{array}{c}\text { Compressional Velocity (km/s) } \\
\text { vs. Pressure (kbar) }\end{array}$} & \\
\hline & & & & 0.1 & 0.2 & 0.3 & 0.4 & 0.5 & 0.6 & \\
\hline \multicolumn{11}{|l|}{ Hole 453} \\
\hline $38-2,8-10$ & 352.6 & 1.62 & $\mathrm{~h}$ & 2.07 & 2.08 & 2.09 & 2.10 & 2.11 & 2.11 & massive mudstone \\
\hline $38-2,11-14$ & - & 1.62 & $\mathbf{v}$ & 2.04 & 2.06 & 2.07 & 2.08 & 2.08 & & \\
\hline mean & - & 1.62 & - & 2.06 & 2.07 & 2.08 & 2.09 & 2.10 & 2.10 & \\
\hline \multicolumn{11}{|l|}{ Hole 459B } \\
\hline $42-1,72-74$ & 388.2 & 1.76 & $\mathrm{~h}$ & 2.15 & 2.16 & 2.18 & 2.20 & 2.22 & 2.33 & silty to sandy vitric tuff \\
\hline $42-1,75-77$ & - & 1.75 & $\mathrm{v}$ & 2.03 & 2.05 & 2.06 & 2.08 & 2.09 & 2.10 & \\
\hline mean & - & 1.76 & - & 2.09 & 2.11 & 2.12 & 2.14 & 2.16 & 2.22 & \\
\hline $44-1,39-41$ & 406.9 & 1.65 & $\mathrm{~h}$ & 2.24 & 2.27 & 2.29 & 2.31 & 2.33 & 2.34 & sandy silty vitric tuff \\
\hline $53-3,75-78$ & 495.7 & 1.73 & $\mathrm{~h}$ & 2.22 & 2.26 & 2.30 & 2.32 & 2.34 & 2.35 & laminated mudstone \\
\hline $53-3,79-83$ & - & 1.70 & $\mathrm{v}$ & 2.05 & 2.08 & 2.11 & 2.14 & 2.17 & 2.19 & \\
\hline mean & - & 1.72 & - & 2.14 & 2.17 & 2.21 & 2.23 & 2.26 & 2.27 & \\
\hline $54-2,56-58$ & 503.6 & 1.95 & $\mathrm{~h}$ & 2.40 & 2.42 & 2.45 & 2.47 & 2.49 & 2.51 & marly limestone \\
\hline $54-2,59-62$ & - & 1.95 & $\mathrm{v}$ & 2.38 & 2.41 & 2.45 & 2.46 & 2.48 & 2.50 & \\
\hline mean & - & 1.95 & - & 2.39 & 2.42 & 2.45 & 2.46 & 2.47 & 2.50 & \\
\hline $55-9,39-41$ & 515.9 & 2.08 & $\mathrm{~h}$ & 2.76 & 2.82 & 2.87 & 2.90 & 2.93 & 2.94 & nannofossil limestone \\
\hline $55-9,42-44$ & - & 2.08 & $\mathrm{v}$ & 2.56 & 2.67 & 2.71 & 2.79 & 2.75 & 2.77 & \\
\hline mean & - & 2.08 & - & 2.66 & 2.75 & 2.79 & 2.85 & 2.84 & 2.86 & \\
\hline $56-1,72-74$ & 521.2 & 2.13 & $\mathrm{~h}$ & 2.07 & 2.10 & 2.13 & 2.16 & 2.18 & 2.20 & $\begin{array}{l}\text { foraminifer-nannofossil } \\
\text { limestone }\end{array}$ \\
\hline
\end{tabular}

$\mathrm{a}_{\mathrm{h}}=$ parallel to bedding; $\mathrm{v}=$ perpendicular to bedding.

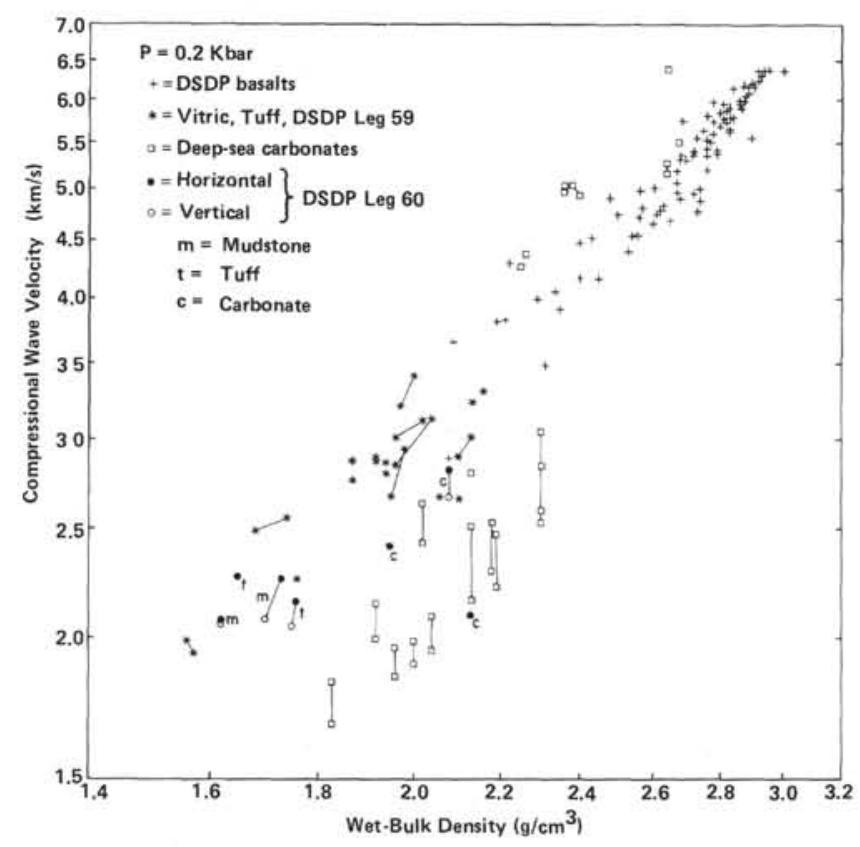

Figure 1. Compressional-wave velocity versus wet-bulk density of sediment samples from DSDP Leg 60. Data for previously studied basalts, carbonates, and vitric tuffs are included for comparison; see text for references. Lines connect data for pairs of samples in which velocities were measured parallel and perpendicular to bedding.

Carlson, R. L., and Christensen, N. I., 1977a. Velocities, densities and elastic constants of basalt and trachytic tuff, DSDP Leg 39. In Supko, P. R., Perch-Nielsen, K., et al., Init. Repts. DSDP, 39: Washington (U.S. Govt. Printing Office), 493-495.

, 1977b. Velocity anisotropy and physical properties of deepsea sediments from the western South Atlantic. In Supko, P. R.,
Perch-Nielsen, K., et al., Init. Repts. DSDP, 39: Washington (U.S. Govt. Printing Office), 555-559.

1979. Velocity anisotropy in semi-indurated calcareous deep-sea sediments. J. Geophys. Res., 84:205-211.

Carlson, R. L., Christensen, N. I., and Wilkens, R. H., in press. Acoustic properties of volcaniclastic sediments recovered from the floor of the Philippine Sea, DSDP Leg 59. In Kroenke, L., Scott, R., et al., Init. Repts. DSDP, 59: Washington (U.S. Govt. Printing Office).

Christensen, N. I., 1970. Compressional wave velocities in basalts from the Juan de Fuca Ridge. J. Geophys, Res., 15:2773-2775. 1973a. Compressional and shear velocities in basaltic rocks, Deep Sea Drilling Project, Leg 16. In van Andel, Tj. H., Heath, G. R., Init. Repts. DSDP, 16: Washington (U.S. Govt. Printing Office), 647-649.

1973b. Compressional and shear velocities and elastic moduli of basalts, Deep Sea Drilling Project, Leg 19. In Creager, J. S., Scholl, D. W., et al., Init. Repts. DSDP, 19: Washington (U.S. Govt. Printing Office), 657-659.

Christensen, N. I., Fountain, D. M., Carlson, R. L., et al., 1974. Velocities and elastic moduli of volcanic and sedimentary rocks recovered on DSDP Leg 25. In Simpson, E. S. W., Schlich, R., et al., Init. Repts. DSDP, 25: Washington (U.S. Govt. Printing Office), 357-360.

Christensen, N. I., Fountain, D. M., and Stewart, R. J., 1973. Oceanic crustal basement: A comparison of seismic properties of DSDP basalts and consolidated sediments. Mar. Geol., 15:215-226.

Christensen, N. I., and Salisbury, M. H., 1972. Sea floor spreading, progressive alteration of layer 2 basalts, and associated changes in seismic velocities. Earth Planet. Sci. Lett., 15:367-375.

1973. Velocities, elastic moduli, and weathering-age relations for Pacific layer 2 basalts. Earth Planet. Sci. Lett., 19:461-470.

Christensen, N. I., Salisbury, M. H., Fountain, D. M., et al., 1974. Velocities of compressional and shear waves in DSDP Leg 27 basalts. In Veevers, J. J., Heirtzler, J. R., et al., Init. Repts. DSDP, 27:445-449.

Nur, A., and Simmons, G., 1969. The effect of saturation on velocity in low porosity rocks. Earth Planet. Sci. Lett., 7:183-193.

Wyllie, M. R. J., Gregory, A. R., and Gardner, G. H. F., 1958. An experimental investigation of factors affecting elastic wave velocities in porous media. Geophysics, 23:459-493. 